\title{
Technogenic soils - soils of the year 2020 in Poland. Concept, properties and classification of technogenic soils in Poland
}

\author{
Cezary Kabała ${ }^{1 *}$, Andrzej Greinert² ${ }^{2}$ Przemysław Charzyński ${ }^{3}$, Łukasz Uzarowicz ${ }^{4}$ \\ ${ }^{1}$ Wrocław University of Environmental and Life Sciences, Institute of Soil Science and Environmental Protection, \\ Grunwaldzka 53, 50-375 Wrocław, Poland; ORCID iD: https://orcid.org/0000-0001-9796-3716 \\ ${ }^{2}$ University of Zielona Gora, Institute of Environmental Engineering, Department of Geoengineering and Reclamation, \\ Prof. Z. Szafrana Str. 15, 65-516 Zielona Góra, Poland; ORCID iD: https://orcid.org/0000-0002-1194-2082 \\ ${ }^{3}$ Nicolaus Copernicus University in Toruń, Faculty of Earth Sciences and Spatial Management, Department of Soil Science and Landscape \\ Management, Lwowska St. 1, 87-100, Toruń, Poland, ORCID iD: https://orcid.org/0000-0003-1467-9870 \\ ${ }^{4}$ Warsaw University of Life Sciences - SGGW, Institute of Agriculture, Department of Soil Science, Nowoursynowska Str. 159, building no. 37, \\ 02-776 Warszawa, Poland, ORCID iD: https://orcid.org/0000-0002-7982-404X \\ * prof. dr hab. C. Kabała, cezary.kabala@upwr.edu.pl
}

Received: 30.09 .2020

Accepted: 11.12 .2020

Associated editor: Ł. Mendyk

\begin{abstract}
The Soil Science Society of Poland has elected technogenic soils to be the Soils of the Year 2020 to highlight the growing understanding of the functions of human-created or significantly human-transformed soils in urban and industrial agglomerations, inhabited by the majority of the human population. Technogenic soils differ greatly in their morphology and physicochemical properties, depending on the kind/way of human intervention and the anthropogenic parent material. Thus, technogenic soils may either form highly productive horticular or park habitats, or unproductive or even toxic sites, which urgently require remediation. This introductory paper presents (a) a history of defining and classification of technogenic soils in Poland, (b) present concept of technogenic soils in the Polish Soil Classification and crucial diagnostics, and (c) a brief review of the subtypes and varieties of technogenic soils, including their recognition in formerly published research reports and correlations with the FAO-WRB classification. The Polish Soil Classification has extended the soil definition to allow classifying soils on buildings and other constructions, and has defined artefacts, geomembrane, hard technogenic layer, thick dumped material and deep soil mixing - new diagnostic properties important for distinguishing and classification of technogenic soils. The type of Technogenic soils includes seven principal subtypes, i.e., Ekranosols, Urbisols, Industriosols, Edifisols, Constructosols, Aggerosols, and Turbisols, as well as three supplementary subtypes, i.e., humus, gleyed and stagno-gleyed.
\end{abstract}

\section{Introduction}

Industrial human activity, mining, urbanization, and development of technical infrastructure for ages have influenced soil cover all over the world. The scale of human-induced pedosphere transformations increased enormously during the $20^{\text {th }}$ century and led to the recognition of man as the sixth factor of soil formation (Dudal, 2004). Presently, at least half of the world population, and in some countries more than $90 \%$ of the population, lives in the areas with significantly transformed or artificially created soils of cities and industrial regions (Morel et al., 2017). Thus, a rapid increase may be noted in the investigation of the origin, properties, and functions of human-transformed and human-made soils, in particular since the 1970s (Skawina, 1958a; Maciak et al., 1974; Dobrzański et al., 1975a 1975b, 1977; Blume and Runge, 1978; Strzyszcz, 1978; Burghardt, 1994).
A growing interest in various groups of technogenic soils can be traced by the increasing number of citations referring to these soils in the Web of Science Core Collection (Fig. 1a). Moreover, a broad spectrum of scientific disciplines covering the investigations of "industrial and technogenic soils" may be noted (Fig. 1b). It includes, apart from soil science, environmental sciences, environmental engineering, water resources, geosciences, applied biotechnology, ecology, agronomy, toxicology, plant sciences, and others. The investigations are carried out world-wide (Fig. 1c) and Poland is among countries with the highest number of citations in this field.

It is clear now that the soils in sites degraded by mining, industry, waste storage, transportation, uncontrolled demolition (like during wars), etc., may play numerous important functions in the ecosystems and landscape, in particular after their intentional or spontaneous remediation (Gwiżdż et al., 2010; Greinert 


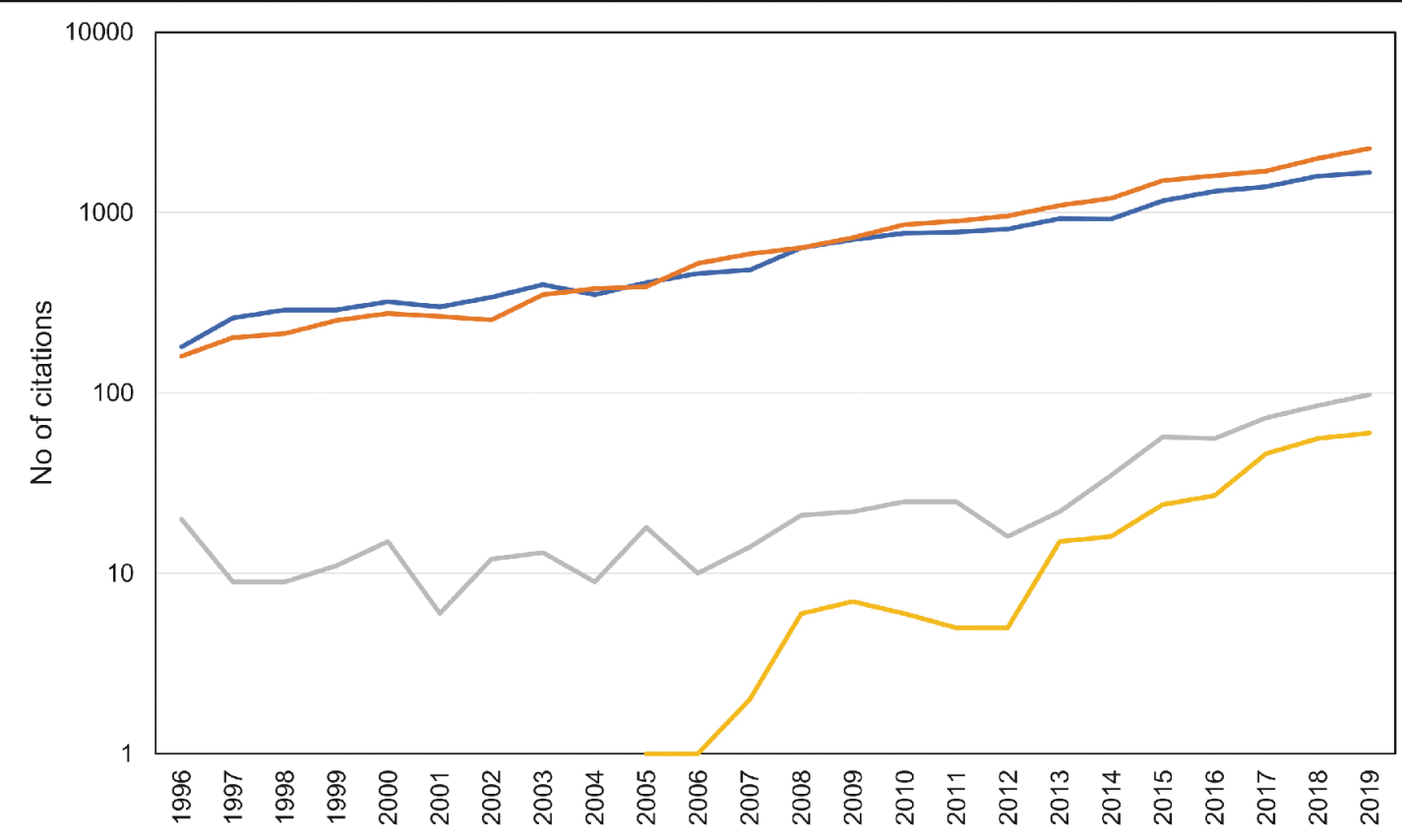

a

—industrial soils —urban soils — technogenic soils - Technosols

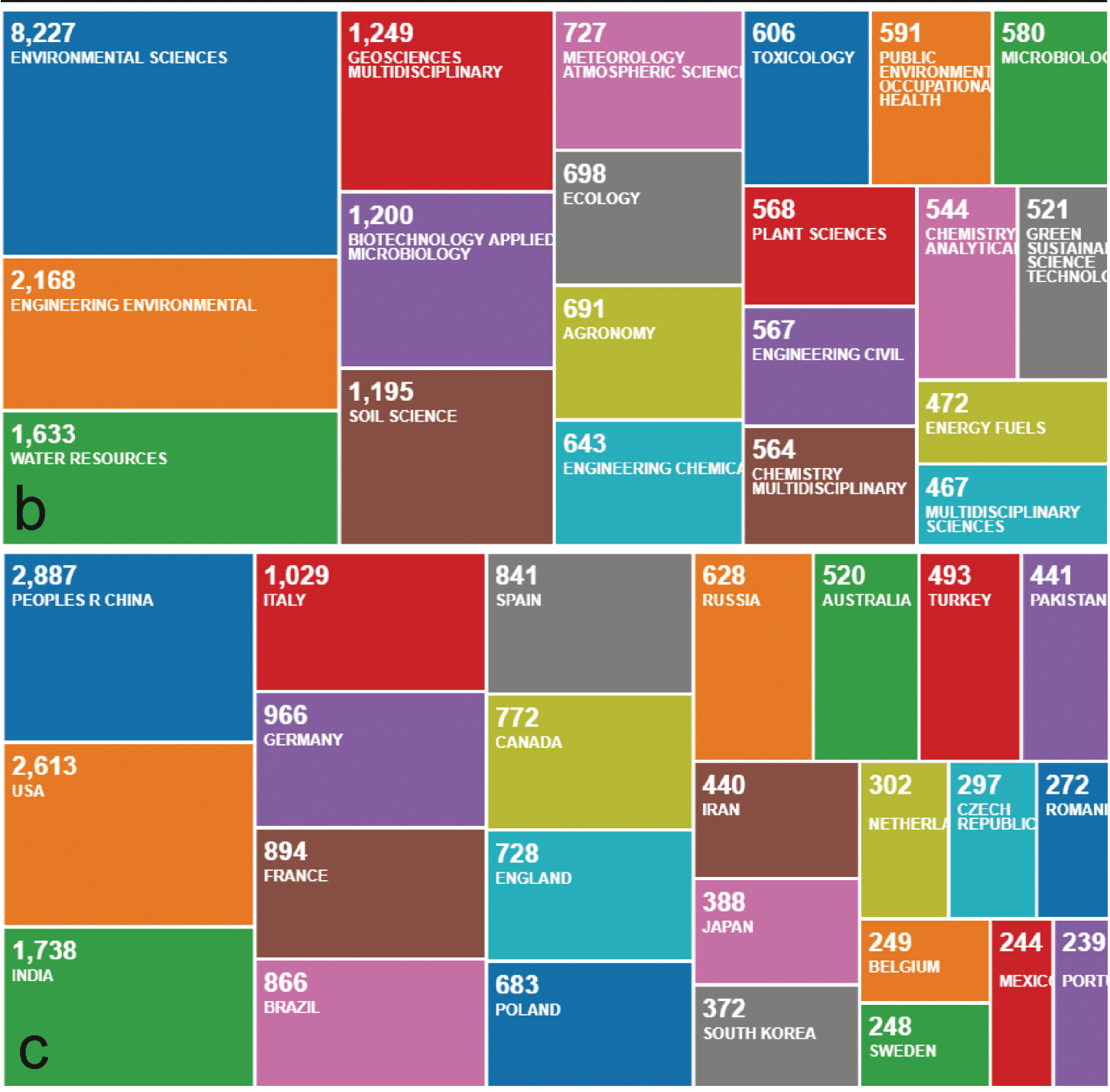

Fig. 1. Visualisation of the scientific interest on technogenic soils based on the Web of Science Core Collection (access in October 2020): (a) a dynamic of a worldwide citation of the terms "industrial soils", "urban soils", "technogenic soils" and "Technosols" in the period 1996-2019; (b) topic disciplines related to the term "industrial and technogenic soils", and (c) distribution of "industrial and technogenic soils" citations by countries 
et al., 2013b), sometimes being the dominant kind of soil and the only available soil for various purposes, including peoples' recreation and food production (Greinert, 2003, 2017; Lehmann and Stahr, 2007; Kabala et al., 2009; Charzyński and Hulisz, 2017; Pindral et al., 2020). However, these soils may also create a risk for human health and for other living organisms, thus they require special attention, including complex characterisation, risk assessment, and permanent monitoring (Rosik-Dulewska and Dulewski, 1989; Karczewska et al., 2005; Uzarowicz, 2011; Dradrach et al., 2019; Kabala et al., 2020).

These issues led the Soil Science Society of Poland to electing the technogenic soils as the soils of the year 2020. The project "Soil of the Year" was invented to spread an information about particular soil types among the broad society, including scientists, farmers, foresters, politicians, teachers and young people, and to encourage scientists to explore the unsolved problems related to a particular soil types. The technogenic soils were elected the third Soil of the Year, after rendzina and chernozem (Kabała, 2018, 2019). One of the involved initiatives is the special issue of the Soil Science Annual with a collection of papers presenting the current state of knowledge on the origin, properties and functions of technogenic soils in Poland and the risks related to these soils. The present text is a kind of introduction to this special issue, dealing mainly with the concept of technogenic soils and their classification problems in Poland.

\section{Brief review of an international context and development of terminology}

Technogenic soils have emerged in soil classification relatively recently. Soil definitions and classifications developed until 1950s highlighted the natural origin of soils, natural factors of their transformation, and soil importance for agricultural and forest production. The soil definitions modified by Kubiëna (1958) and Mückenhausen (1954) allowed the classification of some anthropogenic soils, i.e., those developed or noticeably transformed in the course of horticultural or agricultural activities. Extensive studies in industrial, mining and urbanised areas, in particular carried out since the 1960s in Germany, provided original knowledge on the chemical and physical soil properties in these areas and arguments for their formal inclusion into soil classification schemes (Blume and Runge, 1978; Siem et al., 1987; Blume, 1989; Meuser and Blume, 2001). A recognition of human impact as a $6^{\text {th }}$ factor of soil formation (Dudal, 2004) resulted in a discussion on the uniqueness of pedogenesis under human impact. The terms, such as "anthropedogenesis" (Effland and Pouyat, 1997) and "technopedogenesis” (Solntseva, 2002) were proposed. However, in many technogenic soils, the accumulation/formation of parent material seems more human-related ("anthropogenic lithogenesis") than the subsequent pedogenesis, which may proceed naturally, i.e. without further human contribution, as in non-reclaimed mining heaps (Meuser and Blume, 2001). In the case of soils forming on buildings, both the accumulation of material and its further transformation may occur without any intentional human impact (Charzyński et al., 2015).
No specific term was applied for a long time for a variety of anthropogenic, non-arable soils; thus typically they were named according to their origin or localisation as mining, industrial, or urban soils (Burghardt, 1994). The first version of WRB classification allocated these soils in the Regosols group, considering their poorly developed profiles and strong relation to the parent material, in this case an anthropogenic one (Nachtergaele et al., 2000). Valuable contribution to the classification concepts was provided by the IUSS Working Group 'Soils of Urban, Industrial, Traffic, Mining, and Military Areas' (SUITMA), established in 1998 (Burghardt et al., 2017; Schad, 2018). Numerous well-documented suggestions (Lehmann, 2006; Rossiter, 2007; Charzyński et al., 2013a, 2013b, 2013c; Morel et al., 2015) led to the arising of Technosols as a separate Reference Soil Group in the second edition of WRB in 2006, and its further development in the third WRB edition (IUSS Working Group WRB, 2015). At present, WRB offers the largest opportunity to classify the human-created and human-transformed soils, which undoubtedly contributes to its increasing popularity. It seems a fulfilling of Strzemski's predictions written in "The main ideas of soil taxonomy" (Strzemski, 1971): "The classification that will take into account soil transformation occurring under the influence of the human economy will have the greatest chance of success on a global scale".

Although Technosols are considered conceptually close to SUITMA, some crucial differences have to be highlighted. SUITMA cover all soils of the sites specified in its name, irrespectively of their origin and transformation degree; whereas, the Technosols involve three categories of soils only: (a) soils bearing a significant amounts of artefacts (20-100\% w/w) to the specified depth, or (b) having a constructed geomembrane, or (c) covered with technic hard material or underlain with it at a little depth. The soils intentionally constructed from earthen materials, which do not contain artefacts, are not involved in the Technosol group, even if they form artificial landforms. Furthermore, the soils located on man-made constructions cannot be called Technosols if they are thicker than $5 \mathrm{~cm}$ or do not contain artefacts down to the technic hard material.

SUITMA/Technosols are introduced to the local classification systems to a various extent, depending on the definition of soil accepted by national pedological societies. Thus, apart from the SUITMA and Technosols, also the term 'technogenic soils' is still applied for a naming of undoubtedly human-made or significantly human-transformed soils (Charzyński et al., 2013a, 2013b, 2013c). In this paper, the term "technogenic soils" is used in its meaning defined in the soil classification of Poland (Kabała et al., 2019), broader than the definition of Technosols, but not as such broad as the SUITMA.

\section{History of the technogenic soils in the Polish soil classifications}

Major industrialisation and urbanisation of Poland launched after 1945, apart from numerous economic and social benefits, had an extensive negative impact on the soil cover, regarding both soil naturalness and productivity (Skawina, 1958a; Strzemski, 1955). Thus, the necessity to classify and include these soils 
in soil maps of Poland was reported. Strzemski (1955), probably as one of the first pedologists in Europe, has outlined the specific properties of soil cover in cities and suburban lands, including the mining and industrial activities in these areas, and suggested dividing the urban soils into five groups.

A. Soils developed from natural parent materials: 1) not transformed or only slightly transformed by agricultural operations; 2) markedly transformed by agricultural processes (so-called "garden chernozems");

B. Soils developed from natural but reworked parent materials: 1) soils on mixed grounds; 2) soils in anthropogenic hollows and pits; 3 ) soils on the surface of filled-up ground;

C. Soils developed from natural materials, excavated from some depth and stored in above-ground landforms (heaps), e.g. waste rock from mining and waste earthen materials from digging of tunnels, wells, etc.;

D. Soils developed from artificial (at least in part) materials: 1) soils from construction debris; 2) soils on garbage landfills; 3) soils on heaps of slag, ash and smelting wastes;

E. Artificially constructed soils with a differentiated profile.

These proposals were appreciated by the pedological society in Poland; however, the early soil classifications in the 1950s were created mainly as extended legends on low-scale soil maps (Przyrodniczo-genetyczna klasyfikacja gleb Polski, 1956), where the anthropogenic soils typically cover insufficiently little areas and commonly were omitted. Moreover, the soils of urban and industrial area have still been considered unproductive in terms of agriculture and forestry, therefore ignored. Large-scale remediation works initiated in the 1950s (Skawina, 1958b) have shown the potential usability of these soils for forestry, recreation, and to a lesser extent, for agriculture, and caused the necessity of their professional naming and classification.

For the first time, anthropogenic soils have appeared in the 2nd edition of the Polish Soil Classification (Genetyczna Klasyfikacja Gleb Polski, 1959) as „soils of artificially created landscape forms (e.g., heaps)" in the order of initially developed/raw soils. In the 3rd edition of the Polish Soil Classification (Systematyka Gleb Polski, 1974), the separate two classes (i.e., the highest level of classification) of anthropogenic soils have been distinguished. Culturozems class (Gleby kulturoziemne) included soils having a very thick and humus-rich topsoil horizon, developed mainly in the course of long-term horticultural (Hortisole) and agricultural/forest (Regosole) practices. The class of industrial soils (Gleby industrioziemne) consisted of two groups of (1) soils formed by industrial activity and (2) soils transformed by industrial activity. This classification has omitted the urban soils (if they do not fulfil the criteria for industrial soils or culturozems), but provided a new possibility to classify the saline soils formed under mining or industrial impacts (such as coal mining, ore processing, soda industry etc.), in one class along with natural saline soils.

These statements were considered insufficient, as they did not reflect soil transformation in the course of reclamation (Gołębiowska and Bender, 1983) and the variability of soils in the urban areas (Czerwiński and Pracz, 1990). New studies, carried out in Warsaw (Dobrzański et al., 1975a, 1975b, 1977) and Kraków (Komornicki, 1986), yielded in the proposals of the origi- nal terminology and taxonomy of these soils (Konecka-Betley et al., 1984). Authors divided anthropogenic soils into classes (Urbanosols and Industriosols, Anthrosols), subclasses (forms of land use) and types, based on soil location, origin and physicochemical properties, such as soil $\mathrm{pH}, \mathrm{CaCO}_{3}$ content, base saturation and contamination with trace elements. Following these suggestions, a new soil order (the highest classification level) of anthropogenic soils has been distinguished in the $4^{\text {th }}$ edition of Polish Soil Classification (Systematyka Gleb Polski, 1989), to bring together all soils created or significantly transformed by humans. Two soil types were distinguished within the order. Culturozems type (Gleby kulturoziemne), with two subtypes (Hortisole and Rigosole), inherited the concept of Culturozems class from the previous edition of the classification. The type of industrial and urban soils (Gleby industrio- i urbanoziemne) collected the four most common forms of these soils, listed as subtypes: (a) "anthropogenic soils with unformed profile", which allowed to classify the raw soils on heaps and many urban soils, (b) "anthropogenic humus-enriched soils", for many mechanically and biologically reclaimed industrial and urban soils, (c) "anthropogenic rendzinas", with soils developed from construction debris, mainly in towns, and (d) "anthropogenic saline soils”. These subtypes allowed classifying the majority of anthropogenic soils, which fitted within the contemporary definition of soils.

Growing interest in a sustainable management of resources in cities led since the beginning of the $21^{\text {st }}$ century to numerous new investigations focused on soils, in particular in Zielona Góra (Greinert, 2003). It was highlighted that the soil cover of the town includes both the naturally developed soils and those transformed by human activities, and their qualitative and quantitative differentiation is strongly related to land use. Thus, even the soils considered to have prevailing natural genesis can be in urban areas distinctly different from their analogues in non-urbanised lands. Strongly transformed urban soils should be classified according to the main reason of their transformation, diagnostic properties and ecological function (Greinert, 2003). The investigations initiated in Toruń (Charzyński et al., 2011a, 2011b) provided arguments to include permanently sealed soils (covered with concrete, asphalt, etc.) into soil classification. Also the extensive research in mining and industrial regions confirmed the importance of sufficient pedological terminology and soil classification for land management and for the evaluation of reclamation efficiency (Greinert and Drab, 2000; Krzaklewski and Pietrzykowski, 2002; Znamirowska-Karaś, 2001; Pietrzykowski et al., 2011; Uzarowicz, 2011). The $5^{\text {th }}$ version of Polish Soil Classification (Systematyka Gleb Polski, 2011) has distinguished four, instead of the previous two soil types in the order of anthropogenic soils, by splitting the industrial and urban soils into separate ones, and by adding the saline and salinized soil type (Kabała et al., 2016). In the types of urban and industrial soils, three subtypes were, respectively, distinguished: (a) initially developed, (b) humus enriched, and (c) chemically transformed soils. Moreover, the subtype of sealed soils (Ekranosole) was added to urban soils. Whereas, no further divisions were agreed within the type of saline and salinized soils. 


\section{Present concept and classification of technogenic soils} in Poland

Rapidly growing recognition of soil variability in the urban and industrial agglomerations in recent years, generating the need for adequate pedological concepts and terminology (Greinert, 2003, 2015; Charzyński et al., 2013c, 2017a; Kabała, 2014; Hulisz et al., 2018a), has inspired significant changes in the Polish Soil Classification, launched in its $6^{\text {th }}$ edition (SGP6) (Systematyka Gleb Polski, 2019).

\subsection{Definition of soil}

The definition of soil in SGP6, or more strictly, the definition of the classification object, was constructed in such a way as to indicate clearly which of the natural and anthropogenic accumulations may be classified using the SGP6. Therefore, soil is defined as the accumulation of mineral and organic materials, being the surface part of the lithosphere or connected to the lithosphere by buildings or other permanent constructions, naturally or anthropogenically originated from weathering or accumulation processes, subject to transformation under the influence of soil-forming factors, and able to supply the living organisms with water and nutrients (Kabała et al., 2019).

This definition does not specify the volume of accumulated material or its origin, while its environmental function and susceptibility to further pedogenic transformation are highlighted. Moreover, the soil must be a part of the lithosphere unless it is permanently bound to the lithosphere through the construction.
This means the mineral and organic accumulations on buildings, ruins, fortifications, etc., also these isolated from surface soils, may be classified as soils, but similar materials placed in movable flowerpots (e.g. on windowsill) or accumulated on tractor wheels, trees, etc., are excluded.

\subsection{Diagnostic materials and properties}

The diagnostic horizons, materials and properties, crucial for modern soil classifications (IUSS Working Group WRB, 2015), also got such role in the classification of technogenic soils in SGP6. Anthropogenic diagnostic horizons were specified for culturozemic soils only, while technogenic soils are identified based on diagnostic materials and properties only. These materials and properties are defined in a close relation to WRB (IUSS Working Group WRB, 2015), but not identically.

Artefacts (artefakty) are various materials created or excavated and transported by humans, including the household, construction, mining, and industrial wastes, stored in heaps/ landfills, intentionally formed layers, or admixed to soil profile (Fig. 2). Two kinds of artefacts are distinguished by SGP6 based on their reactivity/toxicity, i.e., normal artefacts (crushed stones, bricks, metals, glass, plastics, etc.) and reactive artefacts (construction lime, ash and slag from metal smelting and coal burning, tailings, mining wastes containing sulphides and elemental sulphur, phosphogypsum, petrochemistry wastes, chemical industry wastes, etc.). The definition of artefacts, both in WRB and SGP6, implies their dissimilarity from the natural materials present at the soil surface in a close surrounding. Thus, the sandy or loamy waste materials stored in the heaps at

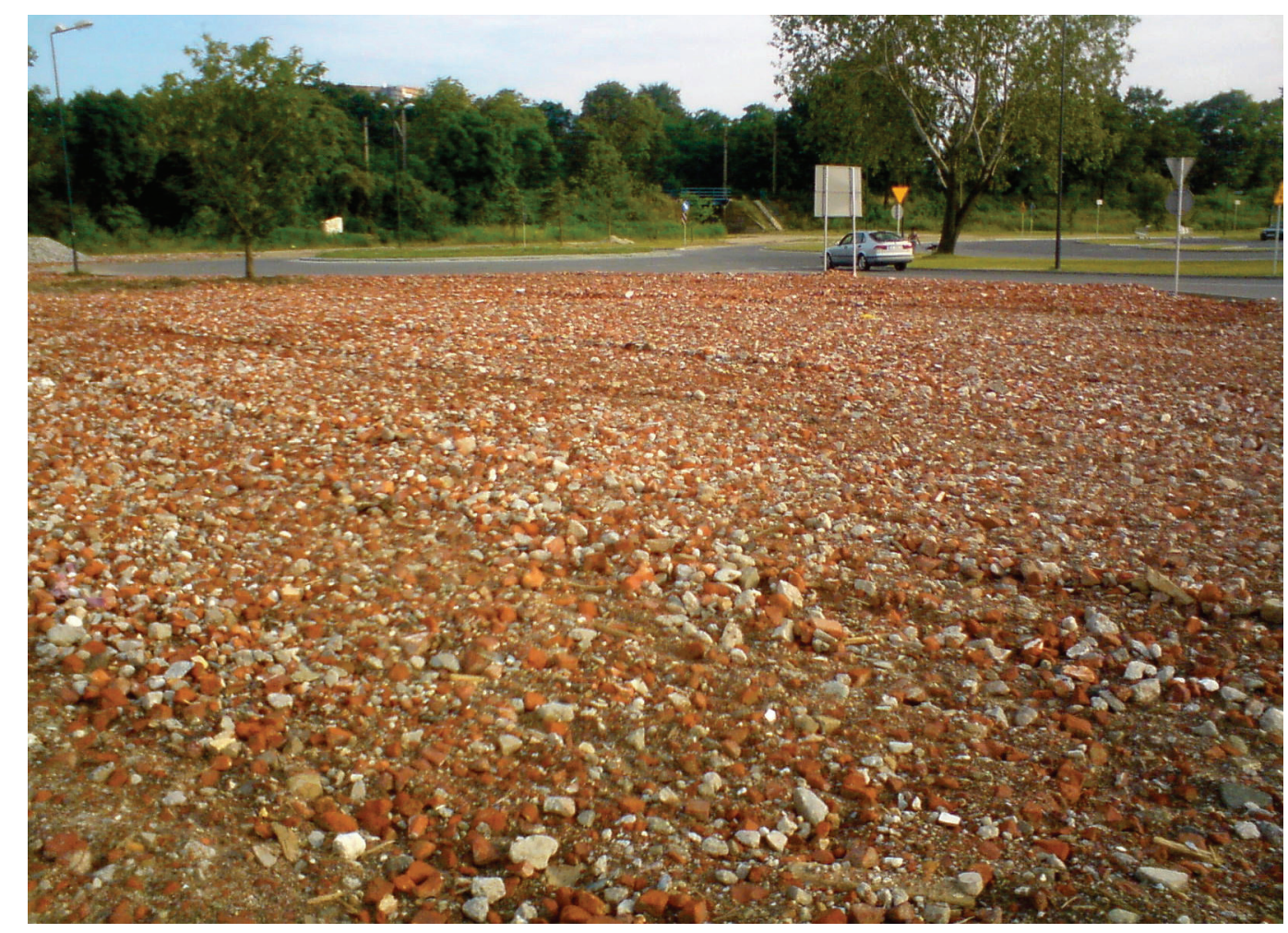

Fig. 2. Artefacts (construction rubble - crushed bricks and concrete) on the soil surface (photo A. Greinert) 


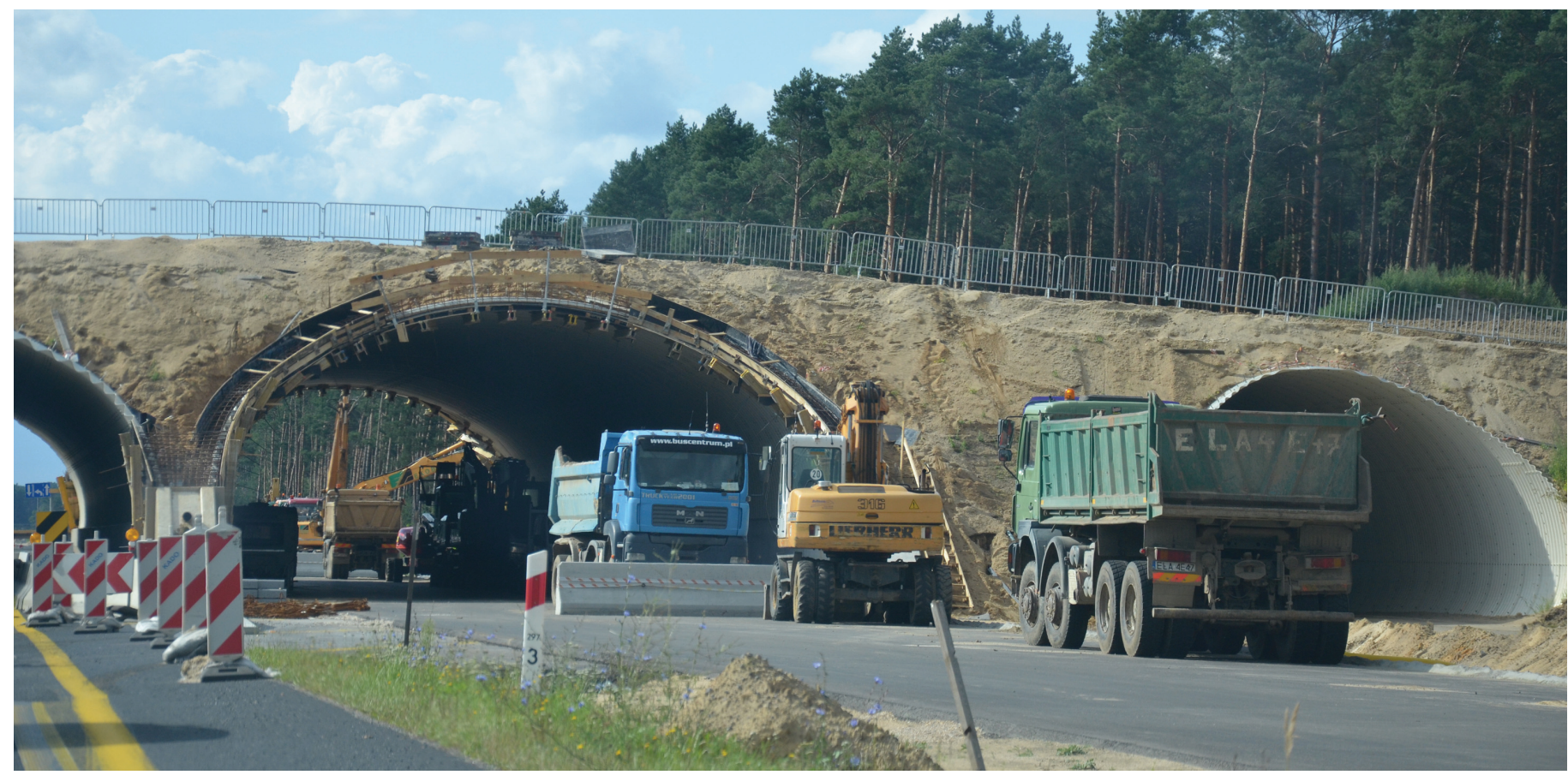

Fig. 3. Thick heap material in the road flyovers - stored directly on earth surface (embankment) or isolated from the surface, i.e. over the constructed tunnel (photo A. Greinert)

the lignite open-cast mines cannot be called artefacts, because similar glacial sands and loams occur in Poland elsewhere at the land surface. To allow the classification of newly formed technogenic soils developed from common Pleistocene materials, if they were excavated, transported and stored in new landforms, SGP6 has defined a thick heap material (głęboki materiat nasypany).

The thick heap material (THM) is a loose, earthen material having $<10 \% /<20 \%$ of artefacts (normal or reactive, respectively), forming an intentionally constructed layer $\geq 50 \mathrm{~cm}$ thick (Fig. 3). The following expression of intentional heaping is required: sharp or distinct boundary to underlying native material, or artefacts in an underlying material (e.g. ash or construction rubble), or forming a mound (heap, embankment, etc.) $\geq 150 \mathrm{~cm}$ high (Kabała et al., 2019). In WRB classification, THM has an equivalent in the Transportic qualifier (IUSS Working Group WRB, 2015).

Among the diagnostic properties, the geomembrane was defined as "synthetic membrane covering the soil surface or dividing soil layers, impermeable or hardly permeable to water and gas” (Kabała et al. 2019). In WRB, the term geomembrane is applied, but not defined.

Technogenic hard layer (lita warstwa technogeniczna, THL) was defined accordingly to technogenic hard material (WRB); however, in SGP6 it was placed among the diagnostic properties, not materials, as such impermeable layer is in fact an external barrier limiting the soil deepening rather than the parent material for soil.

Deep mixing (glębokie wymieszanie) was defined as a deep $(\geq 50 \mathrm{~cm})$ mixing of soil, connected with the destruction of the native soil horizonation (e.g. translocation of fragments of diagnos- tic horizons), due to (1) very deep cultivation, or (2) construction works. In WRB classification, deep mixing has a close equivalent in the Relocatic qualifier (IUSS Working Group WRB, 2015).

\subsection{Classification of technogenic soils}

Based on the extended definition of soil and the presence of diagnostic anthropogenic horizons, properties and materials, the order (the highest-rank unit) of anthropogenic soils (Gleby antropogeniczne) was distinguished in SGP6 and consisting of two soil types: culturozemic soil (Gleby kulturoziemne) and technogenic soils (Gleby technogeniczne).

The culturozemic soils are identified and further divided into subtypes based on the presence of hortik or antrik horizons (at least $50 \mathrm{~cm}$ thick), or deep mixing caused by agricultural, horticultural or forest cultivation.

Whereas, the technogenic soils involve seven principal subtypes and three transitional subtypes, added complimentary to the principal subtypes. All subtypes are listed in a hierarchical order, which highlights the uniqueness of soil properties and their importance for cartography or land use.

Ekranosols (ekranosole) have technogenic hard layer (which is not a part of building or other construction) at the soil surface or at the depth of $\leq 5 \mathrm{~cm}$. These are soils covered with a continuous and impermeable layer of asphalt, concrete, pavement, granite/marble plates, etc., common in the urbanized (squares, streets, cemeteries) and transportation areas (highways, airports, parking sites) (Charzyński et al., 2011b; Kostecki et al., 2020). The soil profile is isolated (sealed) from the top, thus the water, gases, nutrients and xenobiotics may cycle laterally only (Charzyński et al., 2011a; Mendyk and Charzyński, 2016). Also 

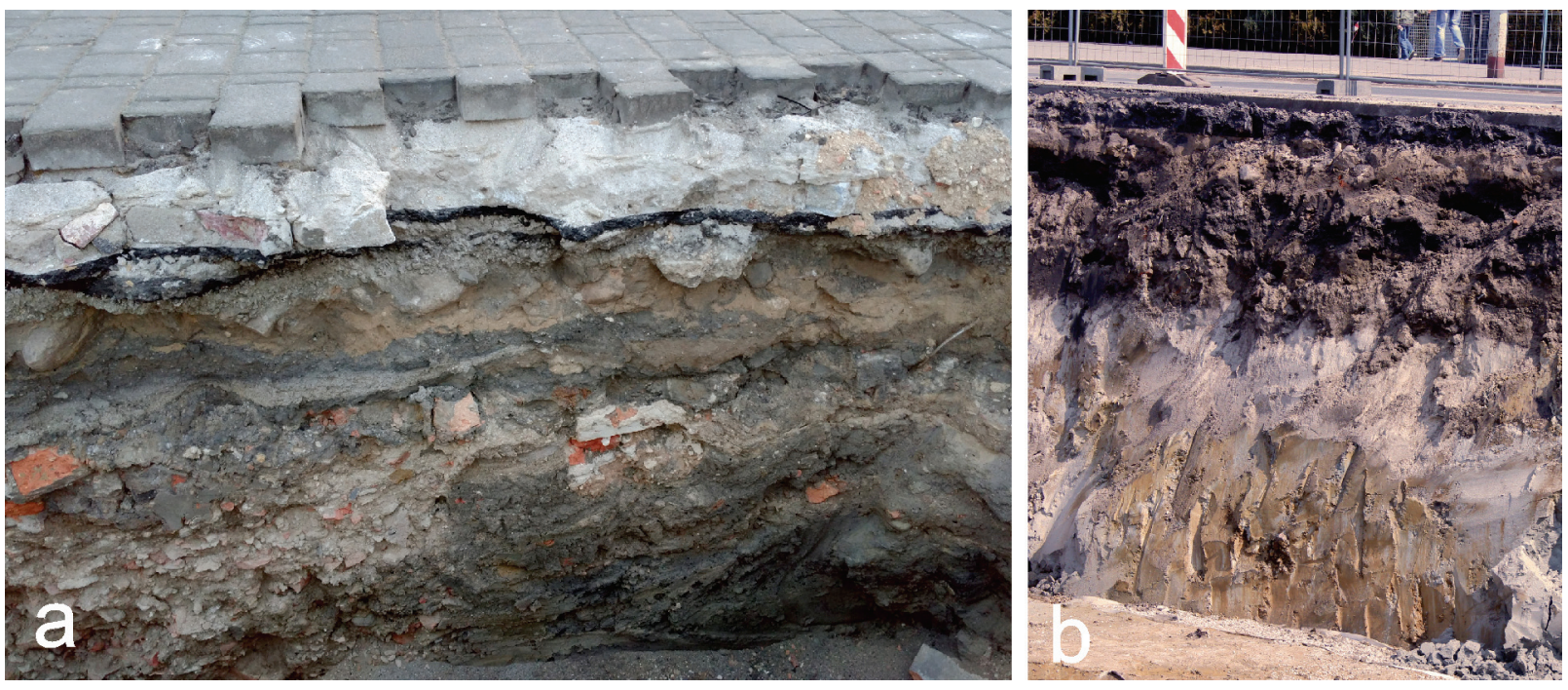

Fig. 4. Ekranosols: (a) sealed with concrete pavement over a mixed layers containing construction debris, (b) sealed with asphalt over a mixed layers and preserved genetic horizons of a native soil (photos A. Greinert)

the organisms may spread laterally from nearby unsealed sites (Piotrowska-Długosz and Charzyński, 2015). The native soil is truncated during the road/pavement construction and replaced with mixed materials, often containing artefacts (Fig. 4a), the subsoil diagnostic horizons (e.g. argik or siderik) are sometimes preserved in ekranosol profiles (Fig. 4b), which may influence the functioning of soil system under the sealing cover. Ekranosols create the most unfavourable space for the living organisms in the urbanized areas, called "concrete deserts" (Greinert, 2017; Lewin et al., 2017). Ekranosols are considered permanently sealed, but the impermeable cover may fracture physically (due to frost action, insolation, etc.) or biologically (the tree root pressure) in the abandoned or neglected sites (Fig. 5), which breaks the sealing continuity and allows the vertical water/nutrient translocation. Ekranosols, as defined by SGP6, are closely related to Ekranic Technosols of WRB classification.

Urbisols (urbisole) contain $\geq 10 \% / \geq 20 \%$ of reactive/normal (respectively) artefacts down to the depth of $100 \mathrm{~cm}$ (or to continuous rock/technic hard layer), which consist mainly of construction rubble, glass, metals, plastic, ash, bones and other wastes connected with human settlements (Fig. 6). Urbisols are typical soils of the city centres, where the long-term construction activi-

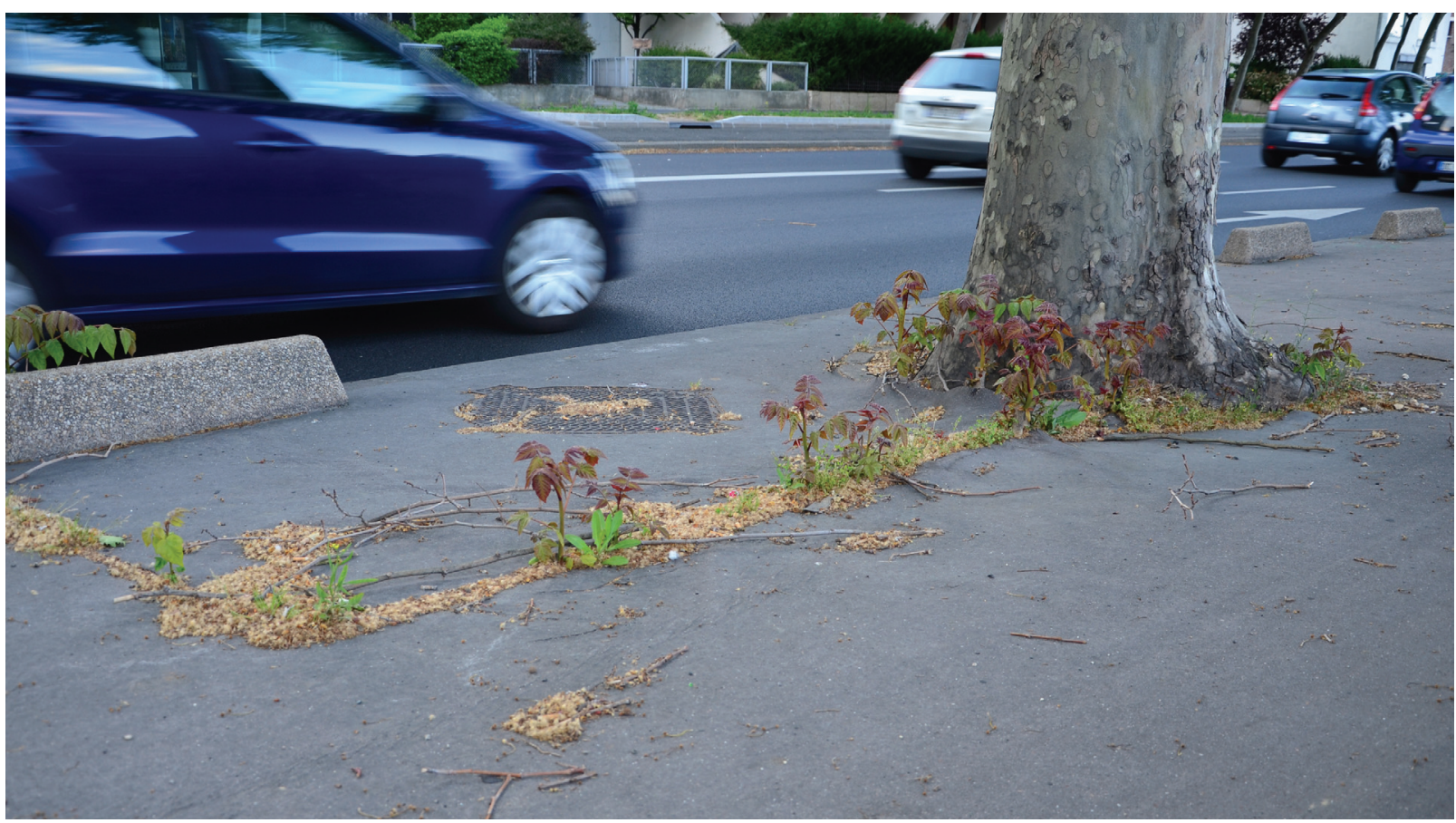

Fig. 5. Cracked, discontinuous surface of Ekranosol destroyed by plant roots (photo C. Kabała) 


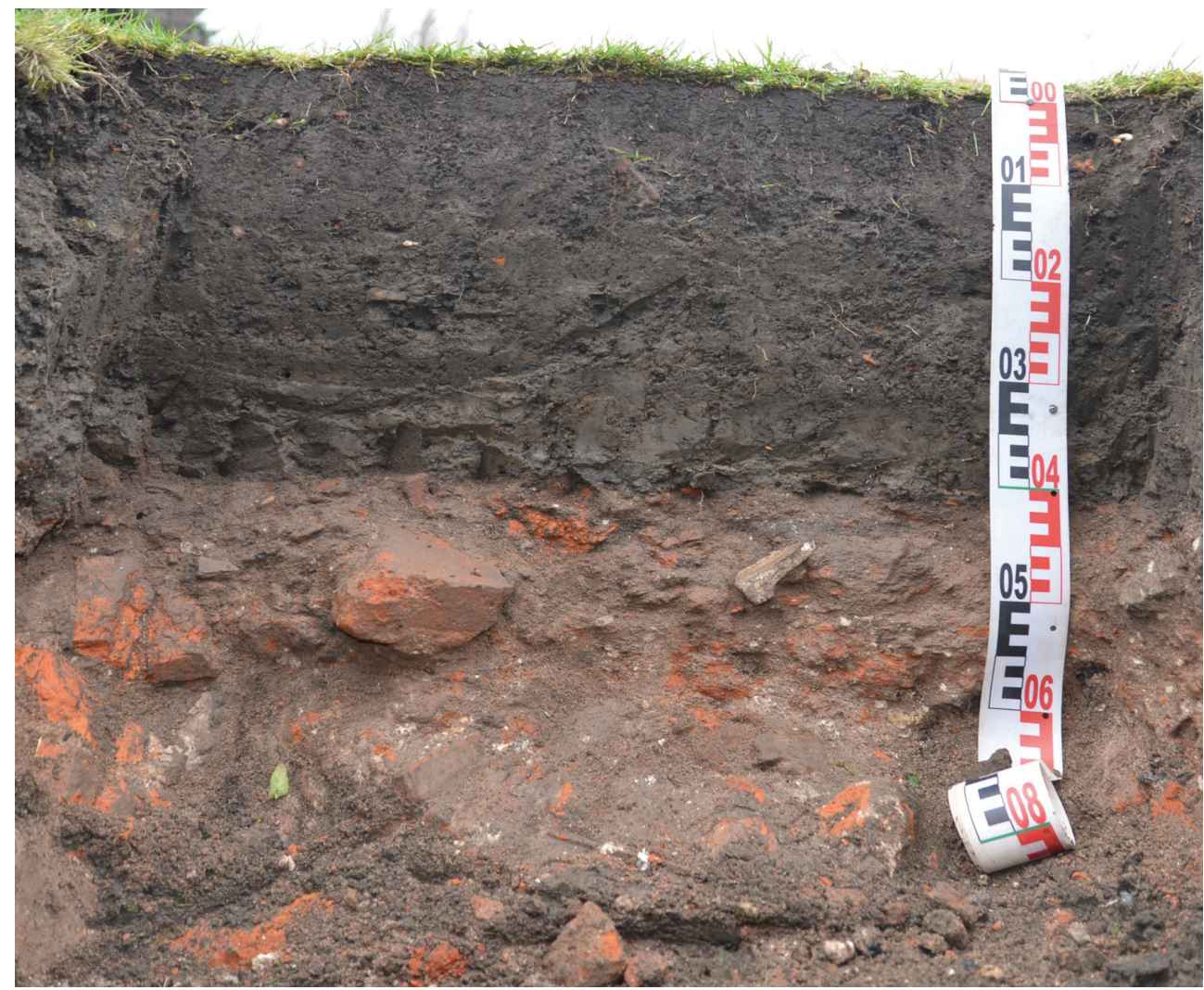

Fig. 6. Urbisol (urbisol próchniczny) developed from the construction debris with humus-rich topsoil created intentionally during site reclamation (photo C. Kabała)

ty (Greinert, 2003, 2015; Greinert et al., 2013a) or simply the longterm human activity connected with surface up-building (Krupski et al., 2017; Mazurek et al., 2016) led to inclusion of diagnostic artefacts. Urbisols are in particular common in the centres of larger Polish towns (Warszawa, Wrocław, Gdańsk, etc.), demolished by bombardments at the end of WW2 (Konecka-Betley et al., 1984; Czerwiński and Pracz, 1990; Charzyński et al., 2013a). Many Urbisols exist in the parks or other sport/recreation sites created on formerly residential areas (Licznar et al., 2007; Kabała et al., 2010; Musielok et al., 2018). Thus, the common feature of the urbisols is the high content of skeleton (crushed construction rubble) and carbonates (Greinert et al., 2013a; Charzyński et al., 2013b). Moreover, urbisols commonly have thick and dark humus horizon, rich in organic matter (due to reclamation), thus the subtype "humic (próchniczne)" is often added as a second subtype. Such urbisols are often featured with high fertility, in particular high content of phosphorus (Greinert, 2003; Charzyński and Hulisz, 2017; Kabala et al., 2018). Urbisols (in terms of SGP6) are similarly defined to Urbic Technosols of WRB classification; however, may contain less artefacts if reactive.

Industriosols (industriosole) contain $\geq 10 \% / \geq 20 \%$ of reactive/ normal (respectively) artefacts down to the depth of $100 \mathrm{~cm}$ (or to continuous rock/technic hard layer), which consist mainly of mining or industrial wastes. Industriosols are typical soils of the heaps and landfills associated with hard/solid rock, coal (Fig. 7a), lignite, sulphur, metal ore mining and processing sites (Fig. 7b) (Znamirowska-Karaś, 2001; Greinert et al., 2013b; Pietrzykowski et al., 2011; Pietrzykowski and Likus-Cieślik, 2018; Uzarowicz, 2011), landfills/heaps of ash and slag from coal/lignite burning (Maciak, 1978; Weber et al., 2015; Uzarowicz et al., 2017,
2018; Gilewska et al., 2020) and landfills of variable industrial wastes (Sutkowska et al., 2015; Zielińska et al., 2017). Also, soils of former factories may contain layers or dispersed admixtures of the industrial wastes (Fig. 7c), sometimes toxic (Charzyński et al., 2013a, 2013b; Kusza et al., 2016). Industriosols may greatly differ in morphological features, texture, physicochemical properties, fertility and toxicity depending on the stored source material. Industriosols are relatively young soils, thus typically their profiles are poorly differentiated into diagnostic horizons (Skawina, 1958b; Strzyszcz, 1978). However, if reclaimed, industriosols may have dark, humus-rich and fertile topsoil horizon (Gołębiowska and Bender, 1983; Woś et al., 2014). Moreover, on the very old heaps associated with metal ore mining and smelting, industriosols may have a well-developed cambic horizon (Karczewska et al., 2005). Industriosols (in terms of SGP6) are similarly defined to Spolic Technosols of WRB classification; however, may contain less artefacts if reactive.

Edifisols (Lat. aedificio - building) are soils existing on the buildings (on the roofs, in the wall cracks, gutters, etc.) where the constructed part of building (or other construction) form a technogenic hard layer, present no deeper than $30 \mathrm{~cm}$ from the soil surface (Fig. 8). Thin soil profile is built of the building remnants - construction rubble (as on ruins) or consists of the allogenic material transported by wind and water, including the organic matter from throughfall (e.g. decomposed leaves). Thus, edifisols may occur as mineral or organic soils, and may greatly differ in physicochemical properties (Charzyński et al., 2015). Mineral edifisols typically contain carbonates and have high $\mathrm{pH}$ values. Edifisols often are enriched with organic matter, including specific kind of humus, called techno-humus (Markiewicz et 

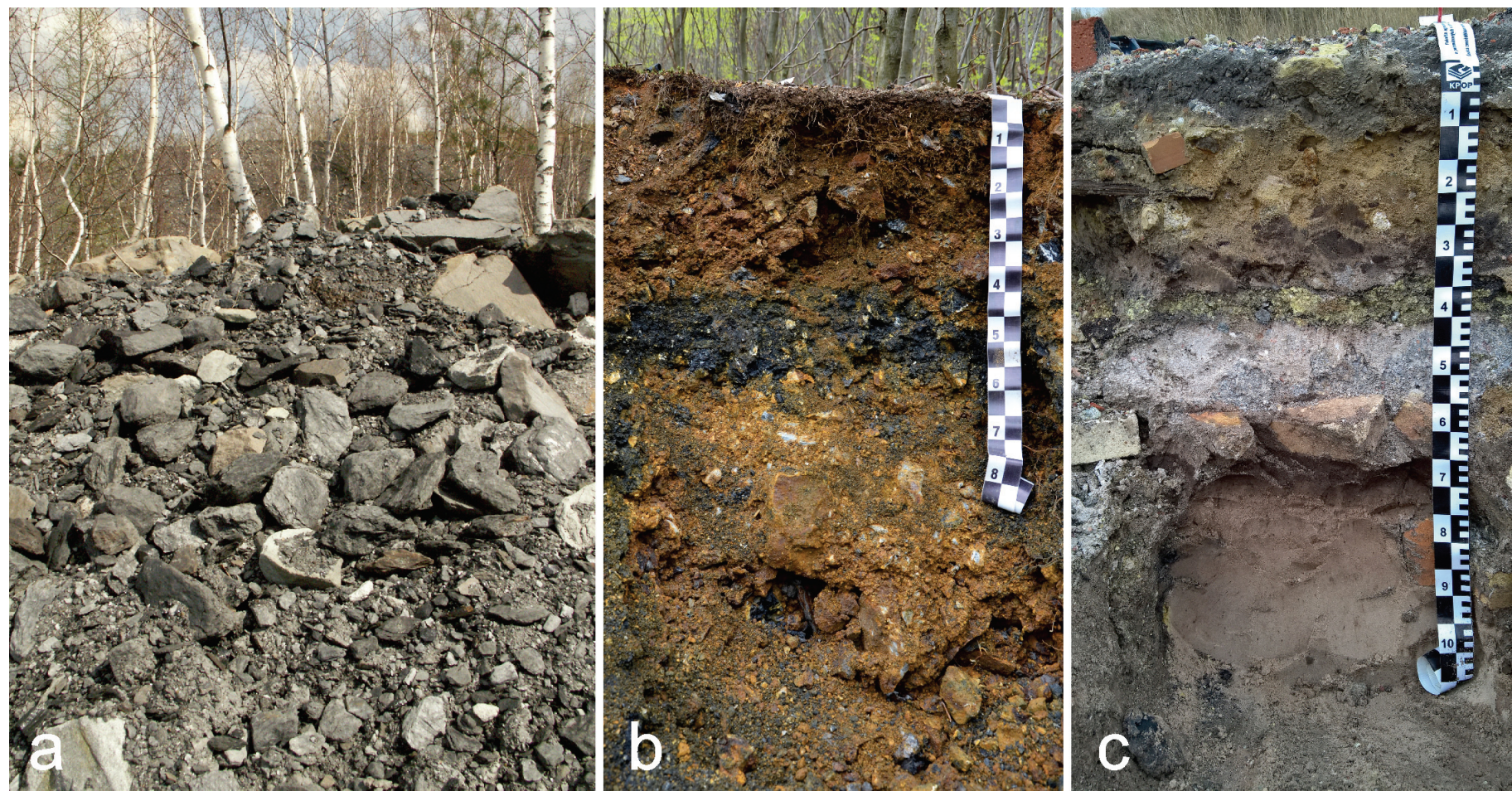

Fig. 7. Industriosols: (a) developed from the dumped coal mining wastes (photo: C. Kabała), (b) developed from the mixed ore mining and smelting wastes (photo: C. Kabała), and (c) stratified industriosol with admixed reactive artefacts (industrial wastes) and construction debris (photo: A. Greinert)
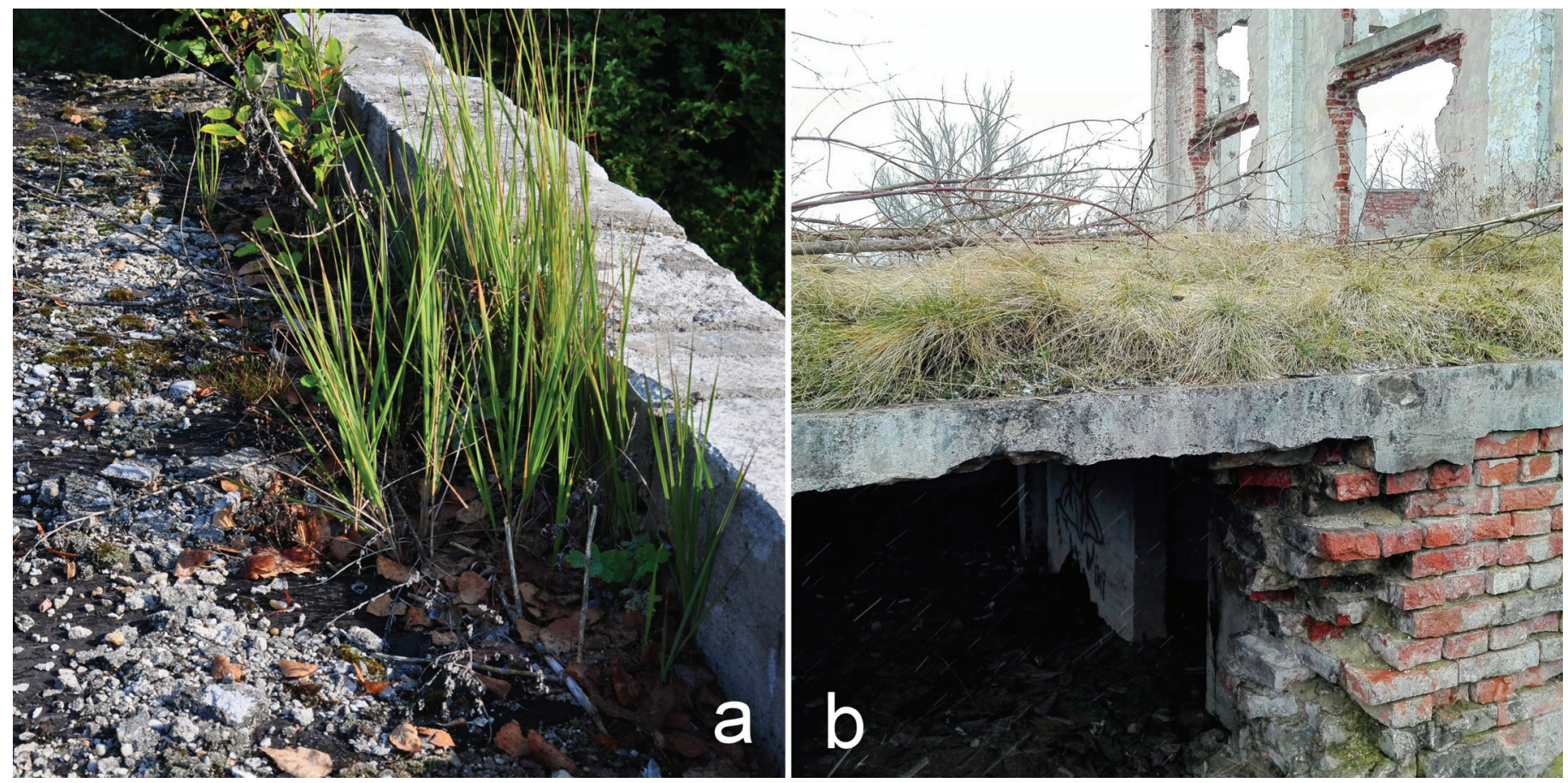

Fig. 8. Edifisols: (a) thin edifisol on the roof of abandoned power substation (photo P. Charzyński), and (b) a vegetation-covered edifisol on the ruined building (photo C. Kabała) 
al., 2018). Due to little profile thickness, most of edifisols have low water capacity and experience droughts in summer. Discontinuous cover of edifisols is non-mappable on most scales. Edifisols (in terms of SGP6) may be correlated with shallow (thinner than $30 \mathrm{~cm}$ ) Isolatic Technosols of WRB classification.

Constructosols (konstruktosole) have a technogenic hard layer or geomembrane starting at the depth of (i) 5-100 cm from the soil surface, or (ii) $30-100 \mathrm{~cm}$ from the soil surface if $T H L$ is a part of building/construction. As evidenced from their definition, constructosols have an impermeable barrier for living organisms, roots, water and nutrients, but located at larger depth as compared to ekranosols or edifisols (Fig. 9). Most commonly, constructosols are situated on the fortifications (Jankowski et al., 2013; Pardela et al., 2020), underground garages, parkings and tunnels, on green roofs, road flyovers (e.g. wildlife passages), etc. Due to drainage requirements, most commonly they have sandy texture, which implies unfavourable physical and chemical properties, excluding constructosols intentionally formed as

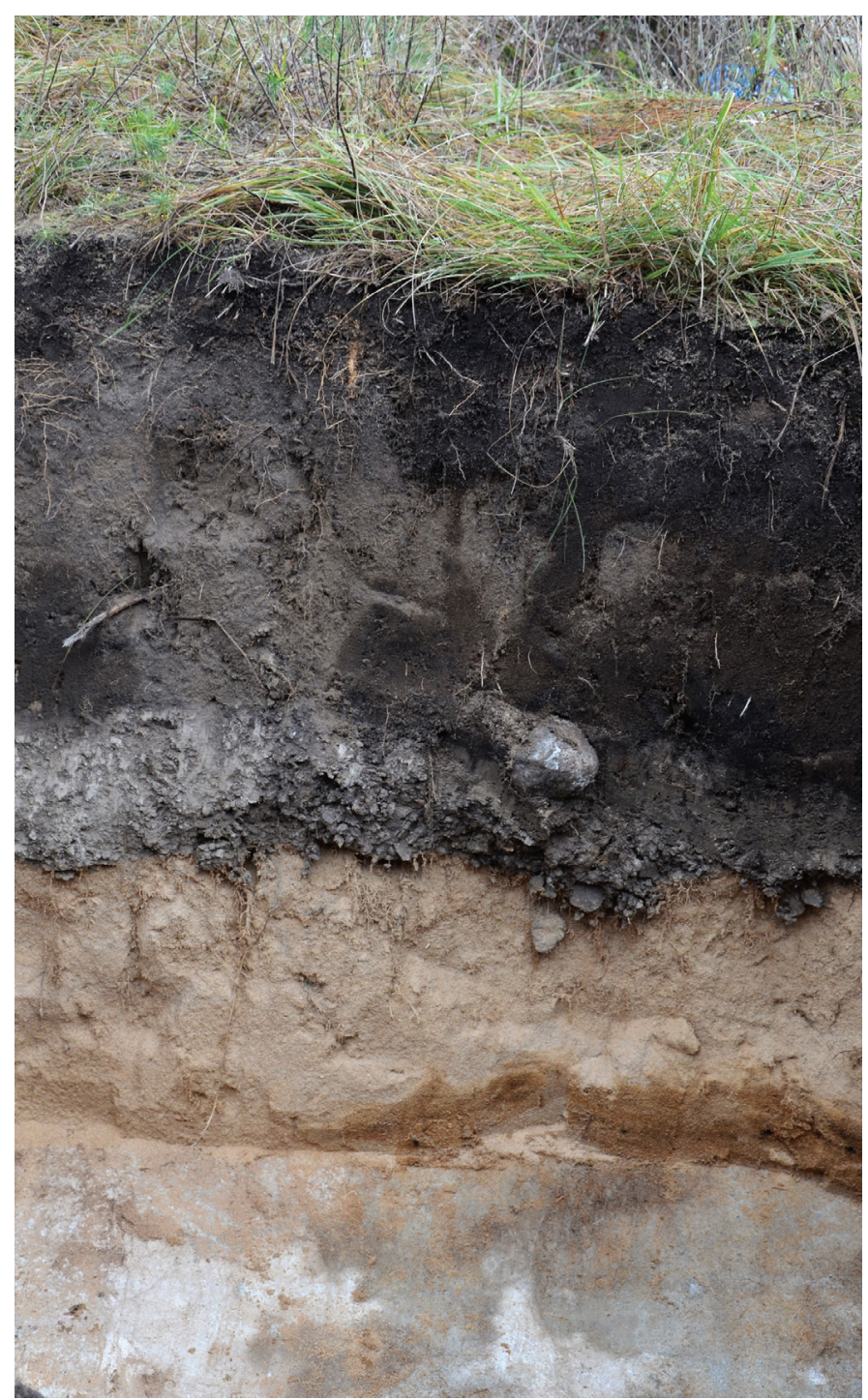

Fig. 9. Sand(gravelly-)-textured Constructosol covering the concrete military fortification (a fortress bunker) (photo C. Kabała) fertile (roof)garden soils. Constructosols are relatively common soils in the modern cities, but the papers reporting their properties are still very few in Poland (Charzyński et al., 2013a). Other case are constructosols existing on landfills and other earthen mounds or embankments, where geomembrane was applied as isolating layer to suppress water and gas cycling. Constructosols (in terms of SGP6) may be correlated with thicker Isolatic Technosols (on the buildings/constructions) or Linic Technosols (when underlain with geomembrane).

Aggerosols (Lat. agger - rampart, dike, embankment) are developed from thick heap material and do not have technic hard layer or geomembrane down to the depth of $100 \mathrm{~cm}$. Typically, these are soils of above-ground artificial landforms, such as dams, road and railway embankments, military earthen fortifications, etc. Alternatively, they occur as infillings of the former excavations or levelling earthen covers surrounding the buildings (Fig. 10a) and industrial constructions (Konecka-Betley et al., 1984). Aggerosols are common soils in the urbanized areas and in transportation channels (railway and highway embankments, Fig. 3). Moreover, the heaps, associated with sand/loam mines and lignite mines, consisting mainly of transported earthen materials and relatively poor in artefacts are common parent material for aggerosols (Fig. 10b). The crucial difference from previously mentioned technogenic soils is a little content of artefacts $(<10 \% /<20 \%$ of reactive/normal artefacts, respectively) and lack of impermeable barrier within soil profile (down to the depth of $100 \mathrm{~cm}$ ). Aggerosols, depending on the reason of their construction, may consist of materials of various texture. Sand-textured aggerosols prevail on road embankments, while the aggerosols in other locations have a texture of neighbouring surface sediments, used to their construction. Common feature of the aggerosols in the levelled residential areas is the large thickness of topsoil humus horizon. According to WRB, aggerosols do not belong to Technosols (due to insufficient content of artefacts), but to the Transportic Regosols.

Turbisols (turbisole) are featured by deep mixing, contain $<10 \% /<20 \%$ of reactive/normal artefacts (respectively), do not consist of thick heap material, and do not have technic hard layer or geomembrane down to the depth of $100 \mathrm{~cm}$. Mixing/disrupting of the soil horizons, typical for these soils, is an associated result of construction works in urbanized, industrial or transportation areas, that was not intentionally oriented on the improvement of soil fertility/productivity, typical for Rigosols. Turbisols may be formed from nearly all natural soil types and may greatly vary in texture and physico-chemical properties (Charzyński et al., 2013a). Compared to the other technogenic soils, they have relatively little admixture of allogenic materials, both earthen materials (sometimes rich in humus) and artefacts. Turbisols are considered common soils in urban and industrial areas; however, it seems they were omitted in most of previous studies as soils lacking spectacular anthropogenic features (Dobrzański et al., 1975a, 1975b; Czerwiński and Pracz, 1990). According to WRB, Turbisols do not belong to Technosols (due to insufficient content of artefacts), but to the Relocatic Regosols.

Beside the above mentioned principal subtypes, the following supplementary subtypes of technogenic soils were distinguished: (i) humus (próchniczne), (ii) gleyed (gruntowo-gle- 

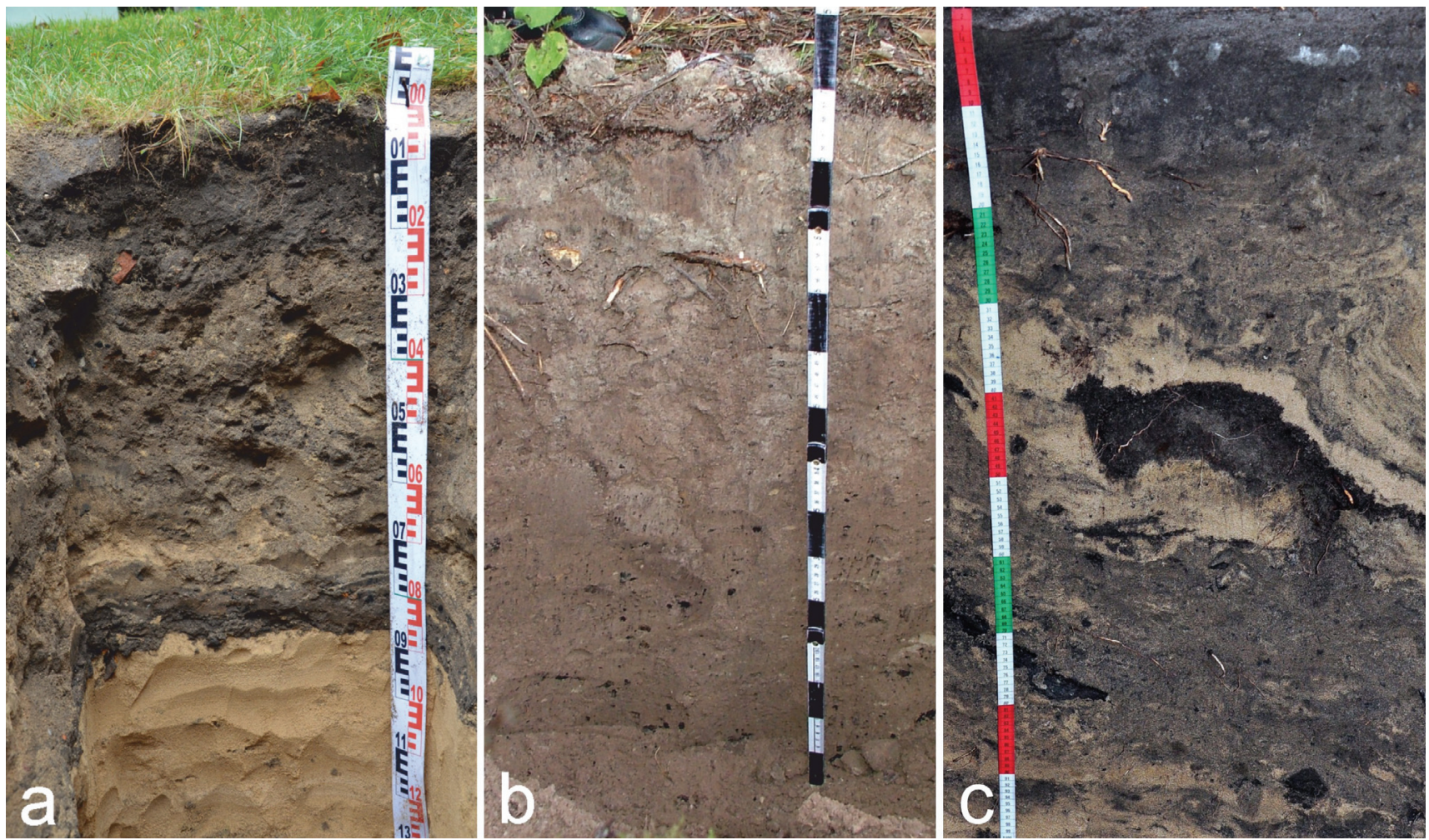

Fig. 10. Aggerosols and Turbisols: (a) sand-textured Aggerosol with little admixture of artefacts (construction rubble) in a residential area (photo C. Kabała), (b) loam-textured Aggerosol with admixture of artefacts (coal fragments) on the heap at a coal mine (photo A. Greinert), and (c) sand-textured Turbisol (photo P. Charzyński).

jowe), and (iii) stagno-gleyed (opadowo-glejowe). These subtypes do not occur separately, but are combined with any of principal subtypes, if respective properties are recognised (e.g. Urbisol próchniczny or Turbisol gruntowo-glejowy).

Classification of anthropogenic salt-affected soils has been discussed many times and various attempts were undertaken in previous Polish Soil Classifications to solve the problem (Systematyka Gleb Polski, 1989, 2011). The primary reason of troubles is the lack of indicators of anthropogenic salinization, different from indicators diagnostic for naturally salt-affected soils (Hulisz, 2007). Moreover, in most reported cases of soils affected by soda industry or coal and metal ore mining/processing, mostly the chemical properties of soils were transformed, while soil morphology, texture and physical properties were less affected or left unchanged, i.e. were similar to respective un-affected soils present in the neighbourhood (Pokojska et al., 1998; Kaszubkiewicz et al., 2003; Ochman et al., 2003; Hulisz et al., 2015). Nevertheless, an appropriate indication of salinization in the soil name/classification seems necessary, as the change in soil chemistry is reflected in the fauna/flora variability (both on a micro, meso- and macroscales) and in the limitations for land use (Czaban et al., 2007; Piernik et al., 2015; Hulisz et al., 2018b; Szymańska et al., 2018). In the 6th edition of Polish Soil Classification (Kabała et al., 2019), salinization and sodification are identified at the level of soil variety, which allows the correct classification of salt-affected soils regardless of the origin of native soil and contamination source. It seems the above approach is the most universal and effective.
Apart from salinization/sodification, numerous other soil features of anthropogenic origin, less intensively marked or less important for soil classification, are listed among soil varieties, the lowest non-hierarchical level of soil classification (Systematyka Gleb Polski, 2019). The varieties may be added to any of soil types/subtypes, if defined criteria are met. Drained (odwodnione) or artificially waterlogged (zawodnione) variety may be applied, if the artificially changed soil water regime influences the soil profile morphology, habitat conditions and land use. Disturbed (zaburzone) and heaped (nasypowe) are analogues of Turbisols and Aggerosols, but the depth of mixing or thickness of heaped material is lower than $50 \mathrm{~cm}$. These varieties are typically displayed in non-technogenic soils. Reclaimed (zrekultywowane) variety refers to various technogenic soils, in particular the industriosols, which have a thick topsoil humus horizon, formed in course of intentional technical or biological reclamation. Soils with well-developed hortik or anthrik horizon, not enough thick to classify the soil to Culturozems (30-50 $\mathrm{cm}$ thick), may be recognised as culturozemic (kulturoziemne) variety. Specific soils developed locally in sites of former charcoal production, and thus highly enriched in charcoal and blackcoloured, are marked as charcoal-pile (pomielerzowe) variety. Contaminated/toxic (skażone/toksyczne) are soils containing such a high content of xenobiotics that their negative effects are recognisable in the field. Anthropo-carbonic, -sulphidic, and sulphatic are varieties of technogenic soils featured by the presence of coal/lignite, sulphides or sulphates, respectively, from anthropogenic sources. 


\section{Closing remarks}

Among the strongly human-transformed or human-constructed soils, the soils of urbanised agglomerations gained recently a spectacular attention, that allowed developing the complex characterisation and classification schemes for soils of urbanised, industrial, mining and traffic areas. Newly introduced soil units and names reflect diversity in origin and properties of the human-affected soils, and commonly refer to their functions in anthropized environments (ecosystem services), which has large importance for spatial planning and sustainable land use. Polish Soil Classification has extended in 2019 the soil definition to allow the classification of soils on buildings and other constructions, and has introduced a number of soil units on a subtype and variety levels to allow naming of variable technogenic soils and anthropogenic transformations in the natural soils. However, the level of recognition of the distinguished subtypes and varieties differs greatly; thus, the further studies are necessary to substantiate their properties, functions and transformations under continuous human impacts. The extended investigations should also support the discussion on new directions and goals of pedology, changes in an understanding and definition of soil, as well as further development of classification of technogenic soils.

\section{References}

Blume, H.P., 1989. Classification of soils in urban agglomerations. Catena 16(3), 269-275.

Blume, H.P., Runge, M., 1978. Genese und Ökologie innerstädtischer Böden aus Bauschutt. Z. Pflanzenernähr. Bodenkd., 141, 727-740.

Burghardt, W., 1994. Soils in urban and industrial environments. Zeitschrift für Pflanzenernährung und Bodenkunde 157 (3), 205$-214$.

Burghardt, W., Morel, J. L., Tahoun, S., Zhang, G. L., Shaw, R. K., Boularbah, A., Charzynski, P., Siebe, C., Kim, K. H. J., 2017. Activities of SUITMA: from origin to future. [In:] Lewin, M.J., Kim, K.-H.J., Morel, J.L., Burghardt, W., Charzyński, P, Shaw, R.K., (Eds.), Soils within cities. Global approaches to their sustainable management - composition, properties, and functions of soils of the urban environment. Schweizerbart Science Publisher, pp. 123-128.

Charzyński, P., Bednarek, R., Błaszkiewicz, J., 2011a. Morphology and properties of Ekranic Technosols in Toruń and Cluj-Napoca. Roczniki Gleboznawcze - Soil Science Annual 62(2), 48-53 (in Polish with English abstract).

Charzyński, P., Bednarek, R., Greinert, A., Hulisz, P., Uzarowicz, Ł., 2013c. Classification of technogenic soils according to WRB system in the light of Polish experiences. Soil Science Annual 64(4), 145-150.

Charzyński, P., Bednarek, R., Świtoniak, M., Żołnowska, B., 2011b. Ekranic Technosols and Urbic Technosols of Toruń Necropolis. Geologia 53(4), 179-185.

Charzyński, P., Galbraith, J.M., Kabała, C., Kühn, D., Prokofeva, T.V., Vasenev, V.I., 2017a. Classification of urban soils. [In:] Lewin, M.J., Kim, K.-H.J., Morel, J.L., Burghardt, W., Charzyński, P, Shaw, R.K., (Eds.), Soils within cities. Global approaches to their sustainable management - composition, properties, and functions of soils of the urban environment. Schweizerbart Science Publisher, 93-106.

Charzyński, P., Hulisz, P., 2017. The case of Toruń, Poland. [In:] Lewin, M.J., Kim, K.-H.J., Morel, J.L., Burghardt, W., Charzyński, P, Shaw, R.K., (Eds.), Soils within cities. Global approaches to their sustainable man- agement - composition, properties, and functions of soils of the urban environment. Schweizerbart Science Publisher, pp. 123-128.

Charzyński, P., Hulisz, P., Bednarek, R., (eds.), 2013a. Technogenic Soils of Poland. Polish Society of Soil Science, Toruń.

Charzyński, P., Hulisz, P., Bednarek, R., Piernik, A., Winkler, A., Chmurzyński, M., 2015. Edifisols - a new soil unit of technogenic soils. Journal of Soils and Sediments 15(8), 1675-1686.

Charzyński, P., Markiewicz, M., Świtoniak, M., (eds.), 2013b. Technogenic Soils Atlas. Polish Society of Soil Science, Toruń.

Czaban, S., Fiałkiewicz, W., Kabała, C., 2007. Potential impact of tailings pond on crop and forest production. Proceedings of the Third International Conference on Environmental Modelling and Simulation (IASTED), EMS, Honolulu, USA, 103-108.

Czerwiński, Z., Pracz, J., 1990. Gleby i kierunki ich transformacji w warunkach presji urbanistycznej. Centralny Program Badań Podstawowych "Funkcjonowanie układów ekologicznych w warunkach zurbanizowanych”. Systematyka i cechy gleb miejskich. Wyd. SGGW, 58, 41-57.

Dobrzański, B., Borek, S., Czarnowska, K., Czerwiński, Z., Czępińska-Kamińska, D., Kępka, M., Konecka-Betley, K., Kusińska, A., Mazurek, A., Pracz, J., 1975a. Badania gleboznawcze Parku Łazienkowskiego w Warszawie w nawiązaniu do ochrony środowiska. Cz. 1. Charakterystyka gleb. Roczniki Nauk Rolniczych, Ser. A, 101(1), 101-140.

Dobrzański, B., Czarnowska, K., Czerwiński, Z., Konecka-Betley, K., Pracz, J., 1975b. Badania gleboznawcze Parku Łazienkowskiego w Warszawie w nawiązaniu do ochrony środowiska. Cz. 2. Wpływ aglomeracji miejskiej na gleby i rośliny. Roczniki Nauk Rolniczych, Ser. A, 101(1), 141-158.

Dobrzański, B., Czerwiński, Z., Pracz, J., Mazurek, A., 1977. Procesy glebowe i właściwości gleb aglomeracji miejskiej na przykładzie Ogrodu Saskiego w Warszawie. Człowiek i Środowisko 1, 33-44.

Dradrach, A., Szopka, K., Karczewska, A., 2019. Ecotoxicity of pore water in soils developed on historical arsenic mine dumps: The effects of forest litter. Ecotoxicology and environmental safety 181, 202-213.

Dudal, R., 2005. The sixth factor of soil formation. Eurasian Soil Science C/C of Pochvovedenie, 38, S60.

Effland, W.R., Pouyat, R.V., 1997. The genesis, classification, and mapping of soils in urban areas. Urban Ecosystems 1, 217-228.

Genetyczna Klasyfikacja Gleb Polski, 1959. Roczniki Gleboznawcze - Soil Science Annual 7(2), 1-131. (in Polish with English summary)

Gilewska, M., Otremba, K., Kozłowski, M., 2020. Physical and chemical properties of ash from thermal power station combusting lignite. A case study from central Poland. Journal of Elementology 25(1), 279-295.

Gołębiowska, J., Bender, J., 1983. Czynniki warunkujące powstawanie poziomu próchniczego w procesie rekultywacji zwałowisk. Archiwum Ochrony Środowiska 1-2, 65-75.

Greinert, A., 2003. Studies on soils of the Zielona Góra urban area. University of Zielona Góra Publ. House, Zielona Góra (in Polish).

Greinert, A., 2015. The heterogeneity of urban soils in the light of their properties. Journal of Soils and Sediments 15(8), 1725-1737.

Greinert, A., 2017. Functions of soils in the urban environment, [In:] Lewin, M.J., Kim, K.-H.J., Morel, J.L., Burghardt, W., Charzyński, P., Shaw, R.K., (Eds.), Soils within cities. Global approaches to their sustainable management - composition, properties, and functions of soils of the urban environment. Schweizerbart Science Publisher, 43-52.

Greinert, A., Fruzińska, R., Kostecki, J., 2013a. Urban soils in Zielona Góra, [In:] Charzyński, P., Hulisz, P., Bednarek, R., (eds.) Technogenic soils of Poland. Torun, Polish Society of Soil Science, 31-54.

Greinert, A., Drab, M., Kostecki, J., Fruzińska, R., 2013b. Post-mining soils in Łęknica region, [In:] Charzyński, P., Hulisz, P. Bednarek, R. (eds.), Technogenic soils of Poland. Torun, Polish Society of Soil Science, 233-253.

Greinert, H., Drab, M., 2000. Physical properties of the soil formed as a result of recultivation of sand-pits in the Bóbr river valley. Acta Agrophysica 35, 77-84. 
Gwiżdż, M., Pruchniewicz, D., Kabała, C., Szopka, K., 2010. Kierunki docelowego zagospodarowania składowisk odpadów wydobywczych na przykładzie wybranych obiektów Wałbrzyskiego i Rybnickiego Okręgu Węglowego. Przegląd Górniczy 66, 78-85.

Hulisz, P., 2007. Proposals of systematics of Polish salt-affected soils. Roczniki Gleboznawcze - Soil Science Annual 58 (1/2), 1-10 (in Polish with English abstract).

Hulisz, P., Charzyński, P., Greinert, A., 2018a. Urban soil resources of medium-sized cities in Poland: a comparative case study of Torun and Zielona Góra. Journal of Soils and Sediments 18, 358-372.

Hulisz, P., Michalski, A., Dąbrowski, M., Kusza, G., Łęczyński, L., 2015. Human-induced changes in the soil cover at the mouth of the Vistula River Cross-Cut. Soil Science Annual 66(2), 67-74. Technogenic layers in organic soils as a result of the impact of the soda industry. Eurasian Soil Science 51(10), 1133-1141.

IUSS Working Group WRB, 2015. World Reference Base for Soil Resources 2014, update 2015. International soil classification system for naming soils and creating legends for soil maps. World Soil Resources Reports No. 106. FAO, Rome.

Jankowski, M., Bednarek, R., Jaworska, M., 2013. Soils constructed on the $19^{\text {th }}$ century fortifications in Toruń. [In:] Charzyński, P., Hulisz, P., Bednarek, R., (Eds.), Technogenic soils of Poland. Polish Society of Soil Science, Toruń.

Kabała, C., 2014. Systematyka gleb Polski - stan aktualny i dalszy rozwój. Soil Science Annual 65, 2, 91-98.

Kabała, C., 2018. Rendzina (rędzina) - soil of the year 2018 in Poland. Introduction to origin, classification and land use of rendzinas. Soil Science Annual 69, 2, 63-74.

Kabała, C., 2019. Chernozem (czarnoziem)-soil of the year 2019 in Poland. Origin, classification and use of chernozems in Poland. Soil Science Annual 70(3), 184-192.

Kabała, C., Buczak, M., Gałka, B., Chodak, T., 2010. Anthropogenic transformations and classification of the soils in rural park in Wroclaw-Pawlowice. Soil Science Annual - Roczniki Gleboznawcze 61(4), 69-77.

Kabała, C., Charzyński, P., Chodorowski, J., Drewnik, M., Glina, B., Greinert, A., Hulisz, P., Jankowski, M., Jonczak, J., Łabaz, B., Łachacz, A., Marzec, M., Mendyk, Ł., Musiał, P., Musielok, Ł., Smreczak, B., Sowiński, P., Świtoniak, M., Uzarowicz, Ł., Waroszewski, J., 2019. Polish Soil Classification, $6^{\text {th }}$ edition - principles, classification. Soil Science Annual 70(2), 71-97.

Kabala, C., Chodak, T., Szerszen, L., Karczewska, A., Szopka, K., Fratczak, U., 2009. Factors influencing the concentration of heavy metals in soils of allotment gardens in the city of Wroclaw, Poland. Fresenius Environmental Bulletin 18(7), 1118-1124.

Kabala, C., Galka, B., Jezierski, P., 2020. Assessment and monitoring of soil and plant contamination with trace elements around Europe's largest copper ore tailings impoundment. Science of The Total Environment, 738, 139918.

Kabala, C., Galka, B., Labaz, B., Anjos, L., de Souza Cavassani, R., 2018. Towards more simple and coherent chemical criteria in a classification of anthropogenic soils: A comparison of phosphorus tests for diagnostic horizons and properties. Geoderma 320, 1-11.

Kabała, C., Świtoniak, M., Charzyński, P., 2016. Correlation between the Polish Soil Classification (2011) and international soil classification system World Reference Base for Soil Resources (2015). Soil Science Annual 67(2), 88-100.

Karczewska, A., Bogda, A., Gałka, B., Krajewski, J., 2005. Assessment of environmental hazards in the vicinity of polymetallic ore deposits Żeleźniak (Wojcieszów-Kaczawskie Mts, SW Poland). Wyd. Akademii Rolniczej we Wrocławiu, 262.

Kaszubkiewicz, J., Ochman, D., Kasina, M., Kisiel, J., Nowacka, S., Szewczyk, A., 2003. Zasolenie gleb w rejonie zbiornika osadów poflotacyjnych „Żelazny Most”. Roczniki Gleboznawcze - Soil Science Annual 54(4), 91-102. (in Polish with English abstract)

Komornicki, T., 1986. Soils of the Planty park in Kraków. Soil Science An- nual - Roczniki Gleboznawcze 37(4), 187-200. (in Polish with English abstract)

Konecka-Betley, K., Janowska, E., Łuniewska-Broda, J., Szpotański, M., 1984. Wstępna klasyfikacja gleb aglomeracji warszawskiej. Roczniki Gleboznawcze - Soil Science Annual 35(2), 151-163 (in Polish with English abstract)

Kostecki, J., Greinert, A., Drab, M., Mik, Ł., 2020. Soil sealing on example of the Jędrzychów Residential Area in Zielona Góra, Poland. Civil and Environmental Engineering Reports 30(1), 53-63.

Krupski, M., Kabala, C., Sady, A., Gliński, R., Wojcieszak, J., 2017. Doubleand triple-depth digging and Anthrosol formation in a medieval and modern-era city (Wrocław, SW Poland). Geoarchaeological research on past horticultural practices. Catena 153, 9-20.

Krzaklewski, W., Pietrzykowski, M. 2002. Selected physico-chemical properties of zinc and lead ore tailings and their biological stabilisation. Water Air and Soil Pollution 141(1-4), 125-142.

Kubiëna, W., 1958. The classification of soils. Journal of Soil Science, 9(1), 9-19.

Kusza, G., Gołuchowska, B., Szewczyk, M., 2016. Changes in physicochemical properties of soils in the area affected by lime industry. Ecological Chemistry and Engineering A 23(4), 433-442

Lehmann, A., 2006. Technosols and other proposals on urban soils for the WRB [World Reference Base for Soil Resources]. International agrophysics 20(2), 129-134.

Lehmann, A., Stahr, K., 2007. Nature and significance of anthropogenic urban soils. Journal of Soils and Sediments 7(4), 247-260.

Lewin, M.J., Kim, K.-H.J., Morel, J.L., Burghardt, W., Charzyński, P, Shaw, R.K., 20147. Soils within cities. Global approaches to their sustainable management - composition, properties, and functions of soils of the urban environment. Schweizerbart Science Publisher.

Licznar, S.E, Licznar, M., Licznar, P., 2007. Monitoring środowiska: Badania pokrywy glebowej Parku Szczytnickiego we Wrocławiu. Inst. Badań Systemowych PAN, Badania Systemowe 53, 104 pp.

Maciak, F., Liwski, S., Biernacka, E., 1974. Some physico-chemical and biochemical properties of the ash dumps after brown and hard coal. Roczniki Gleboznawcze - Soil Science Annual 25(3), 191-205 (in Polish with English abstract).

Maciak, F., 1978. Effect of the seven-year recultivation on an ash dump of the Konin power plant on yielding of cocksfoot and some changes of soil. Roczniki Gleboznawcze - Soil Science Annual 29(3), 203-216 (in Polish with English abstract).

Markiewicz, M., Hulisz, P., Charzyński, P., Piernik, A., 2018. Characteristics of soil organic matter of edifisols - An example of techno humus system. Applied Soil Ecology 123, 509-512.

Mazurek, R., Kowalska, J., Gąsiorek, M., Setlak, M., 2016. Micromorphological and physico-chemical analyses of cultural layers in the urban soil of a medieval city - A case study from Krakow, Poland. Catena 141, 73-84.

Mendyk, Ł., Charzyński, P., 2016. Soil sealing degree as factor influencing urban soil contamination with polycyclic aromatic hydrocarbons (PAHs). Soil Science Annual 67(1), 17-23.

Meuser, H., Blume, H.P., 2001. Characteristics and classification of anthropogenic soils in the Osnabrück area, Germany. Journal of Plant Nutrition and Soil Science 164(4), 351-358.

Morel, J.L., Burghardt, W., Kim, K.-H.J., 2017. The challenges for soils in the urban environments. [In:] Lewin, M.J., Kim, K.-H.J., Morel, J.L., Burghardt, W., Charzyński, P, Shaw, R.K., (Eds.), Soils within cities. Global approaches to their sustainable management - composition, properties, and functions of soils of the urban environment. Schweizerbart Science Publisher, pp. 123-128.

Morel, J.L., Charzyński, P., Shaw, R.K., Zhang, G., 2015. The seventh SUITMA conference held in Toruń, Poland, September 2013. Journal of Soils and Sediments 15(8), 1657-1658.

Mückenhausen, E., 1954. A tentative classification scheme of the soil of Germany. TAO. Meeting f. Soil Classification. Gand. 
Musielok, Ł., Drewnik, M., Stolarczyk, M., Gus, M., Bartkowiak, S., Kożyczkowski, K., Wątły, M., 2018. Rates of anthropogenic transformation of soils in the Botanical Garden of Jagiellonian University in Kraków (Poland). Catena 170, 272-282.

Nachtergaele, F.O., Spaargaren, O., Deckers, J.A., Ahrens, B., 2000. New developments in soil classification: world reference base for soil resources. Geoderma 96(4), 345-357.

Ochman, D., Kaszubkiewicz, J., Kasina, M., Nowacka, S., 2003. Changes of physical and physico-chemical properties of soils under the influence of highly mineralized trickling waters from the tailings impoundment äIron Bridgeö. Zeszyty Problemowe Postepow Nauk Rolniczych 493, 833-838.

Pardela, Ł., Kowalczyk, T., Bogacz, A., Kasowska, D., 2020. Sustainable Green Roof Ecosystems: 100 Years of Functioning on Fortifications - A Case Study. Sustainability 12(11), 4721.

Piernik, A., Hulisz, P., Rokicka, A., 2015. Micropattern of halophytic vegetation on technogenic soils affected by the soda industry. Soil Science and Plant Nutrition, 61 (sup1), 98-112.

Pietrzykowski, M., Krzaklewski, W., Piechnik, Ł., 2011. Soil characteristics on afforested areas after calamine mining. Roczniki Gleboznawcze - Soil Science Annual 62(2), 325-334 (in Polish with English abstract).

Pietrzykowski, M., Likus-Cieślik, J., 2018. Comprehensive study of reclaimed soil, plant, and water chemistry relationships in highly S-contaminated post sulfur mine site Jeziórko (Southern Poland). Sustainability 10, 2442.

Pindral, S., Kot, R., Hulisz, P., Charzyński, P., 2020. Landscape metrics as a tool for analysis of urban pedodiversity. Land Degradation and Development, 1-14. https://doi.org/10.1002/ldr.3601

Piotrowska-Długosz, A., Charzyński, P., 2015. The impact of the soil sealing degree on microbial biomass, enzymatic activity, and physicochemical properties in the Ekranic Technosols of Torun (Poland). Journal of Soils and Sediments 15, 47-59.

Pokojska, U., Bednarek, R., Hulisz, P., 1998. Problemy systematyki gleb zasolonych $\mathrm{w}$ odniesieniu do obszaru objętego wpływem IZCH „SODA-MĄTWY S.A.”. Zeszyty Problemowe Postępów Nauk Rolniczych 460, 513-521.

Przyrodniczo-genetyczna klasyfikacja gleb Polski ze szczególnym uwzględnieniem gleb uprawnych. 1956. Roczniki Nauk Rolniczych 74-D, 1-96. (in Polish with English summary)

Rosik-Dulewska, C., Dulewski, J., 1989. The chemical composition and the content of selected radionuclides in plants cultivated on an ash dump of the Halemba power plant. Roczniki Gleboznawcze - Soil Science Annual 40, 151-169.

Rossiter, D.G., 2007. Classification of urban and industrial soils in the world reference base for soil resources (5 pp). Journal of Soils and Sediments 7(2), 96-100.

Schad, P., 2018. Technosols in the World Reference Base for Soil Resources-history and definitions. Soil Science and Plant Nutrition 64(2), 138-144.

Siem, H.K., Cordsen, E., Blume, H.P., Finnern, H., 1987. Klassifizierung von Böden anthropogener Lithogenese vorgestellt an Beispiel von Böden im Stadtgebiet Kiel. Mitteilungen der Deutsche Bodenkundlichen Gesellschaft 55/II, 831-836.

Skawina, T., 1958a. The processes of soil deterioration in mining and industrial regions. Roczniki Gleboznawcze - Soil Science Annual 7 (suppl.), 131-148. (in Polish with English abstract)
Skawina, T., 1958b. The development of soil formation processes on the waste heaps of the coal industry. Roczniki Gleboznawcze - Soil Science Annual 7 (suppl.), 149-162 (in Polish with English abstract).

Solntseva, N.P., 2002. Trends in soil evolution under technogenic impacts. Eurasian soil science 35, 6-16.

Strzemski, M., 1955. Problems of urban soil science. Przegląd Geograficzny 27(3-4), 579-587 (in Polish with English abstract).

Strzemski, M., 1971. Myśli przewodnie systematyki gleb. PWRiL Warszawa, IUNG Puławy, Seria P, 16, 580 pp.

Strzyszcz, Z., 1978. Chemiczne przemiany utworów karbońskich w aspekcie biologicznej rekultywacji i zagospodarowania centralnych zwałowisk. Prace i Studia PAN 19 (in Polish, with English summary).

Sutkowska, K., Teper, L., Stania, M., 2015. Tracing potential soil contamination in the historical Solvay soda ash plant area, Jaworzno, Southern Poland. Environmental Monitoring and Assessment 187, 704.

Systematyka Gleb Polski. 1974. Roczniki Gleboznawcze - Soil Science Annual 25(1), 1-149. (in Polish with English summary)

Systematyka Gleb Polski. 1989. Roczniki Gleboznawcze - Soil Science Annual 40(3/4), 1-150. (in Polish with English summary)

Systematyka Gleb Polski. 2011. Roczniki Gleboznawcze - Soil Science Annual 62(3), 1-193. (in Polish with English summary)

Systematyka Gleb Polski. 2019. Soil Science Society of Poland, Commission on Soil Genesis, Classification and Cartography. Wydawnictwo Uniwersytetu Przyrodniczego we Wrocławiu, Polskie Towarzystwo Gleboznawcze, Wrocław-Warszawa, 235 pp. (in Polish with English summary).

Szymańska, S., Borruso, L., Brusetti, L., Hulisz, P., Furtado, B., Hrynkiewicz, K., 2018. Bacterial microbiome of root-associated endophytes of Salicornia europaea in correspondence to different levels of salinity. Environmental Science and Pollution Research 25(25), 25420-25431.

Uzarowicz, Ł., 2011. Technogenic soils developed on mine spoils containing iron sulfides in select abandoned industrial sites: Environmental hazards and reclamation possibilities. Polish Journal of Environmental Studies 20(3), 771-782.

Uzarowicz, Ł., Kwasowski, W., Śpiewak, O., Świtoniak, M., 2018a. Indicators of pedogenesis of Technosols developed in an ash settling pond at the Bełchatów thermal power station (central Poland). Soil Science Annual 69, 49-59.

Uzarowicz, Ł., Zagórski, Z., Mendak, E., Bartmiński, P., Szara, E., Kondras, M., Oktaba, L., Turek, A., Rogoziński, R., 2017. Technogenic soils (Technosols) developed from fly ash and bottom ash from thermal power stations combusting bituminous coal and lignite. Part I. Properties, classification, and indicators of early pedogenesis. Catena 157, 75-89.

Weber, J., Strączyńska, S., Kocowicz, A., Gilewska, M., Bogacz, A., Gwiżdż, M., Dębicka, M., 2015. Properties of soil materials derived from fly ash 11 years after revegetation of post-mining excavation. Catena 133, 250-254.

Woś, B., Pietrzykowski, M., Krzaklewski, W., 2014. Properties of humus in soils formed on afforested dumping ground of the sulphur mine. Sylwan 158, 893-900.

Zielińska, S., Radkowski, P., Ossowski, T., Ludwig-Gałęzowska, A., Łoś, J.M., Łoś, M., 2017. First insight into microbial community composition in a phosphogypsum waste heap soil. Acta Biochimica Polonica 64, 693-698.

Znamirowska-Karaś, I., 2001. The soil forming processes depending on the waste material of mica-schist, loam dumps in the Sudety Mts. Zeszyty Naukowe Uniwersytetu Zielonogórskiego 133, 95-102. 